This paper is based on the second George Brown Lecture, delivered at the seminar 'Clays: Mineralogy, Interactions with Organics and Industrial Applications', held at the University of Huddersfield on $10^{\text {th }}$

October 2001

\title{
Chemically modified smectites
}

\author{
P. KOMADEL* \\ Institute of Inorganic Chemistry, Slovak Academy of Sciences, SK-845 36 Bratislava, Slovakia
}

(Received 7 January 2003; revised 18 February 2003)

\begin{abstract}
This paper summarizes recent results obtained on chemical modifications of smectites. These include replacement of exchangeable cations with protons, a process connected with smectite autotransformation - attack of protons on the layers and liberation of central atoms from the octahedral and tetrahedral sheets, causing modification of the acid sites on the particles. More severe modifications occur during dissolution in inorganic acids, when the layers are dissolved and threedimensional amorphous silica is formed. The negative charge on the smectite layers can be increased via reduction of structural $\mathrm{Fe}$ (III) to $\mathrm{Fe}$ (II) or decreased via fixation of small exchangeable cations, such as $\mathrm{Li}^{+}$, upon treatment at elevated temperatures. Heating for $24 \mathrm{~h}$ at different temperatures between 100 and $300^{\circ} \mathrm{C}$ leads to a series of chemically similar materials of different charge, prepared from the same parent mineral. Such series are suitable for investigation of the effect of the layer charge on selected properties of smectites. Fe(II) can be partly stabilized in reduced smectites by $\mathrm{Li}$ fixation upon heating.
\end{abstract}

KEYwORDS: H-smectites, acid dissolution, charge modification, Li fixation, reduction.

Bentonites are abundant clay ores. Most of their properties, such as fine particle size, high surface area and cation exchange capacity (CEC), surface acidity, etc., are typical properties of smectites, the dominant clay minerals in bentonites. Chemical modifications of smectites, such as acid activation, $\mathrm{Fe}$ (III) reduction, fixation of cations, or their combination, affect substantially the layers of smectite, together with their most important properties and applications. This has been our reason for extensive investigation of fine fractions of various bentonites and effects of different chemical modifications. The most common alteration of smectites is the substitution of exchangeable cations. It is abundant in the nature as well as in the laboratories. Many papers report that pure homoionic forms were prepared via repeated ion

* E-mail: uachkomp@ savba.sk

DOI: $10.1180 / 0009855033810083$ exchange and subsequent washing of the solid phase obtained. However, detailed quantitative analyses of exchangeable cations rarely appear and if performed correctly, usually prove that the product is not a true homoionic smectite (e.g. Low, 1980).

\section{$H$-smectites}

$\mathrm{H}$-smectites differ from other forms due to their instability; the surface and interlayer protons attack the layers in a similar fashion to protons from strong inorganic acids (Barshad, 1969). This instability has probably contributed to the lack of appeal of these materials for extensive investigation. On the other hand, acid sites are very important, mainly for catalytic and sorption properties, and H-smectites are usually a component of bleaching earths and other acid-activated materials. Therefore we have investigated them in detail. Dioctahedral smectites differ substantially in their 
swelling ability (Low, 1980). H-smectites, like Naand Li-forms, are good swelling materials (Norrish, 1954), some capable of forming voluminous sediments (Komadel \& Číčel, 1987, 1988; Komadel \& Schomburg, 1993). This property decreases with ageing but can be stabilized by treatments with $\mathrm{Na}$ salt solutions (Komadel \& Číčel, 1991). These assays suggested that substantial changes in surface acidity of $\mathrm{H}$-smectites occur upon ageing.

The greatest proton saturation of the $<2 \mu \mathrm{m}$ fractions of bentonites were obtained by first saturating with $\mathrm{Na}^{+}$ions using $1 \mathrm{M} \mathrm{NaCl}$ solution, then dispersions were prepared and treated with a solution of $1 \mathrm{M} \mathrm{NaCl}+0.1 \mathrm{M} \mathrm{Na}_{2} \mathrm{C}_{2} \mathrm{O}_{4}+0.1 \mathrm{M} \mathrm{HCl}$ to remove easily soluble iron and aluminium oxide/ hydroxides. The dispersions of Na-smectites were passed through a train of three columns under applied suction. The first and third columns were filled with Amberlit IR-120 resin in the $\mathrm{H}^{+}$form, and the second with Wofatit SBW resin in the $\mathrm{OH}^{-}$ form to ensure maximal saturation with protons (Barshad, 1969; Janek et al., 1997; Janek \& Komadel, 1993, 1999).

Potentiometric titrations of fresh and aged proton-saturated forms were used to characterize the acid centres at the smectite-water interface of dioctahedral smectites. The ageing of the dispersions occurred at $90^{\circ} \mathrm{C}$ and finished within 4 days. This sample preparation procedure ensured maximal saturation with protons for the very beginning of the experiment with their molar amount equal to the CEC of smectite. After the protons had replaced the original exchangeable cations, they were consumed in the process of autotransformation. Titration data were entered into the thermodynamic calculation of proton affinity distribution using the SAIEUS program (Jagiełło, 1994). Numerical solving of an integral adsorption equation provided the continuous distribution of proton interacting sites for the smectites investigated. The proton affinity distributions identified up to five different proton interacting sites in all the proton-saturated smectite/water systems, within the accessible experimental range of $\mathrm{pHs}$ between 2 and 12. The isotherms of freshly prepared $\mathrm{H}$-forms showed titration of both strong and weak acid sites (Fig. 1). The number of the strongest acid sites, i.e. those with the lowest $\mathrm{p} K$ values, decreased on ageing, while the number of all weaker acid sites increased with autotransformation. The number of strong acid sites varied among samples and accounted for $60-95 \%$ of the total acidity in the freshly prepared $\mathrm{H}$-forms. The strongest acid sites were connected with free protons present in the dispersion, while the weaker acid sites were connected with the titration of $\mathrm{Al}^{3+}, \mathrm{Fe}^{3+}$ and $\mathrm{Mg}^{2+}$ cations released from the structure and/or their hydrolysed species, together with the deprotonation of functional $\mathrm{SiOH}$ groups (Janek \& Komadel, 1999).

The layer-charge distributions of all smectites investigated were heterogeneous. Oxalate pretreatment of the samples resulted in changes in the layer-charge distribution due to the removal of readily soluble phases which may have blocked exchange sites. After autotransformation, the alkylammonium exchange method revealed heterogeneous charge-density distributions wherein the fraction of layers of the highest charge was decreased. Comparison of total CEC, obtained from potentiometric curves, and interlamellar CEC, calculated from the mean layer charge confirmed the attack of protons in the particle edges. However, for several samples the structural attack may also occur in the interlayer space. Autotransformation of the $\mathrm{H}$-smectites decreased the mean layer charge, suggesting that protons attack preferentially the $\mathrm{Mg}(\mathrm{O}, \mathrm{OH})_{6}$ octahedra during the autotransformation (Janek et al., 1997).

\section{Acid activation}

Though dissolution of smectites in inorganic acids of different concentrations is a very common chemical treatment, several questions remain to be answered. Dissolution occurs in nature through the attack of acid mine waters or weathering and it is also used in industry. Acid activation, i.e. partial dissolution of smectites in inorganic acids, is a common treatment applied to produce sorbents (bleaching earths), catalysts or catalyst supports, carbonless copying papers, etc. (Siddiqui, 1968; Adams, 1987; Brown, 1994; Fahn \& Fenderl, 1983). As might be expected, the process of acid dissolution of smectites is affected by the temperature, acid concentration, acid/clay ratio and stirring, with significant differences occurring between reactions in closed and open systems. Closed systems, with no addition or removal of any substance in the course of reaction, are more common for experiments performed in laboratories, while open systems are typical for processes occurring in nature. Continuous addition 


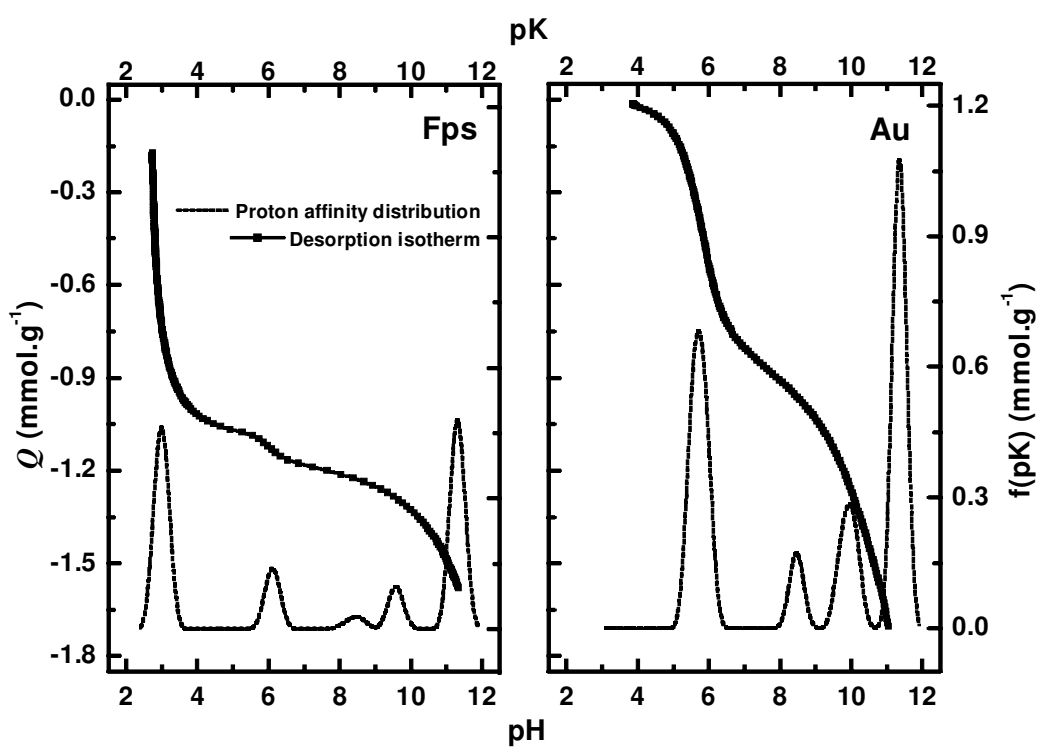

FIG. 1. Recalculated proton adsorption isotherms of SAz-1 montmorillonite and revealed proton affinity distributions. Fps - fresh prepared sample, Au-after autotransformation. Data from Janek \& Lagaly (2001).

of fresh acid, though usually of much lower concentration than in most laboratory experiments, causes substantial dissolution of relatively resistant layer silicates, such as pyrophyllite (Lintnerová et al., 1999). Direct comparison of results obtained for closed and open systems can lead to erroneous conclusions.

Several methods have been used to follow the extent of smectite dissolution in acids, including chemical analysis (CA) of the liquid and/or solid reaction products, X-ray diffraction, infrared (IR) spectroscopy, magic angle spinning nuclear magnetic resonance (MAS NMR) spectroscopy, thermal analysis, surface area measurements, etc. Comparison of the sensitivity of these techniques, their availability in the laboratories and time needed per analysis favour IR spectroscopy, since the spectra are very sensitive to modifications of the mineral structure upon acid treatment. As protons penetrate into the clay layers and attack the $\mathrm{OH}$ groups, the resulting dehydroxylation connected with successive dissolution of the octahedral sheet can be readily followed by intensity decreases in the hydroxyl-bending vibrations of $\mathrm{Al}_{2} \mathrm{OH}$ and $\mathrm{AlMgOH}$ at 915 and $842 \mathrm{~cm}^{-1}$, respectively (Farmer, 1974). The Si-O-Al bending vibration near $520 \mathrm{~cm}^{-1}$ is the most sensitive band to the presence of residual $\mathrm{Al}$ in the octahedral sheet (Fig. 2). A gradual transformation of the tetrahedral sheet to a three-dimensional framework of protonated amorphous silica can be observed in the region of the stretching vibrations of Si-O groups. Changes in the Si environment with prolonged acid treatment are reflected in both the position and the shape of the Si-O-stretching band near $1050 \mathrm{~cm}^{-1}$. The component near $1100 \mathrm{~cm}^{-1}$, assigned to $\mathrm{Si}-\mathrm{O}$ vibrations of amorphous silica with a threedimensional framework, appeared and increased in

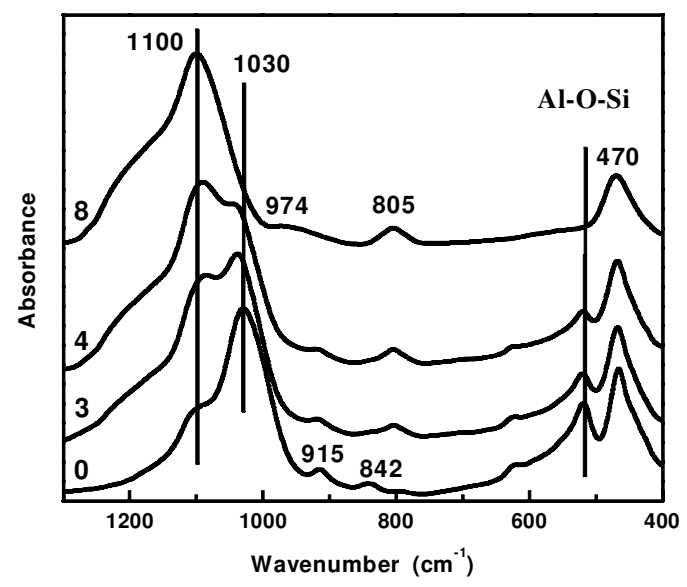

FIG. 2. IR spectra of montmorillonite SAz-1 treated in $6 \mathrm{M} \mathrm{HCl}$ at $80^{\circ} \mathrm{C}$ for $0,3,4$ and $8 \mathrm{~h}$. Data from Madejová et al. (1998). 
intensity with increasing severity of acid treatment. The characteristic smectite absorption bands are absent from the spectrum of the sample treated for $8 \mathrm{~h}$ and only the bands of amorphous silica at 1100 , 805 and $470 \mathrm{~cm}^{-1}$ are observed. The broad band near $974 \mathrm{~cm}^{-1}$ is due to the $\mathrm{Si}$-O-stretching vibration of $\mathrm{SiOH}$ groups (Moenke, 1974), which are present in the three-dimensional product formed as the octahedral sheet in the smectite layer becomes substantially depleted (Madejová et al., 1998).

Chemical analysis of leaching solutions and IR and MAS NMR spectroscopy of the prepared solids were used for analysis of acid-treated hectorite (Komadel et al., 1996b). ${ }^{27} \mathrm{Al}$ MAS NMR spectra proved that the small amount of $\mathrm{Al}$ present in hectorite occurred in both tetrahedral and octahedral sheets and both forms were released to the solution upon acid treatment. Solution analysis showed that $\mathrm{Li}$ dissolved slightly faster than $\mathrm{Mg}$ at weaker acid concentrations, thus indicating that protons preferentially attacked the more negative Li octahedra compared to Mg-octahedra. The difference diminished at higher acid concentrations. Relative intensities of the Si-O-stretching bands of hectorite near $1015 \mathrm{~cm}^{-1}$ and of free silica near $1100 \mathrm{~cm}^{-1}$ provided direct information on the dissolution of the mineral. Progressive increases in the content of amorphous silica in the samples was reflected in the increasing intensities of the Si-O bands near 1100 and $800 \mathrm{~cm}^{-1}$ and in the decreasing absorption of the $\mathrm{Si}-\mathrm{O}$ vibration of the tetrahedral sheets near $1015 \mathrm{~cm}^{-1}$. The IR spectra of the acid dissolution product obtained from hectorite did not exhibit an absorption band near $1015 \mathrm{~cm}^{-1}$, but did show intense bands near 1100 and $800 \mathrm{~cm}^{-1}$ and a broad absorption band near $965 \mathrm{~cm}^{-1}$, attributed to $\mathrm{Si}-\mathrm{O}$ stretching vibrations of $\mathrm{SiOH}$ groups. As much as $37 \%$ of total $\mathrm{Si}$ atoms, identified by ${ }^{29} \mathrm{Si}$ MAS $\mathrm{NMR}$ as $\mathrm{Si}$ in $\mathrm{Si}(\mathrm{OSi})_{3} \mathrm{OH}$ and $\mathrm{Si}(\mathrm{OSi})_{2}(\mathrm{OH})_{2}$ environments, contributed to the absorption near $965 \mathrm{~cm}^{-1}$. Analysis of relative peak intensities of the components in the ${ }^{29} \mathrm{Si}$ MAS NMR spectra (Gates et al., 1996) provided direct dissolution data, concordant with the $\mathrm{Mg}$ contents in the leaching solutions (Fig. 3). The changes in the environment of $\mathrm{Si}$ atoms in the tetrahedra upon acid treatment occurred at a rate similar to the dissolution of octahedral Mg. The progressive changes in IR and ${ }^{29} \mathrm{Si}$ MAS NMR spectra of hectorite and montmorillonite due to acid dissolution are alike. A combination of these spectroscopies is extremely useful to probe structural changes occurring during acid dissolution of smectites (Breen et al., 1995a,b; Gates et al., 1996; Komadel et al., 1996b; Madejová et al., 1998; Tkáč et al. (1994).

Substitution of the exchangeable cations by hydrated protons is much faster than dissolution of the mineral layers and the effect of structural composition on the acid dissolution of smectites is significant. Trioctahedral smectites dissolve much faster than their dioctahedral counterparts (Madejová et al., 1998). Novák \& Číčel (1978) showed that the rate of dissolution of dioctahedral smectites in $\mathrm{HCl}$ increases with the substitution of $\mathrm{Fe}$ and $\mathrm{Mg}$ for $\mathrm{Al}$ in the octahedral sheet. A smaller amount of octahedral substitution is one of the reasons for the slower dissolution rate of pyrophyllite compared to montmorillonite. Moreover, the effect of swelling interlayers on the dissolution rate has been experimentally proven only recently (Komadel et al., 1996a). It was postulated that different rates of dissolution of tetrahedral and octahedral $\mathrm{Al}(\mathrm{III})$ and $\mathrm{Fe}(\mathrm{III})$ in acids would serve as an experimental basis to distinguish between portions of these atoms bound in the tetrahedral and octahedral sheets (Ostahaus, 1956; Novák \& Číčel, 1978). Later, the Mössbauer study of Luca \& MacLachlan (1992) and the MAS NMR assay of Tkáč et al. (1994) confirmed that acid treatment removes $\mathrm{Fe}(\mathrm{III})$ and $\mathrm{Al}(\mathrm{III})$, respectively, from the tetrahedral and octahedral sheets of dioctahedral

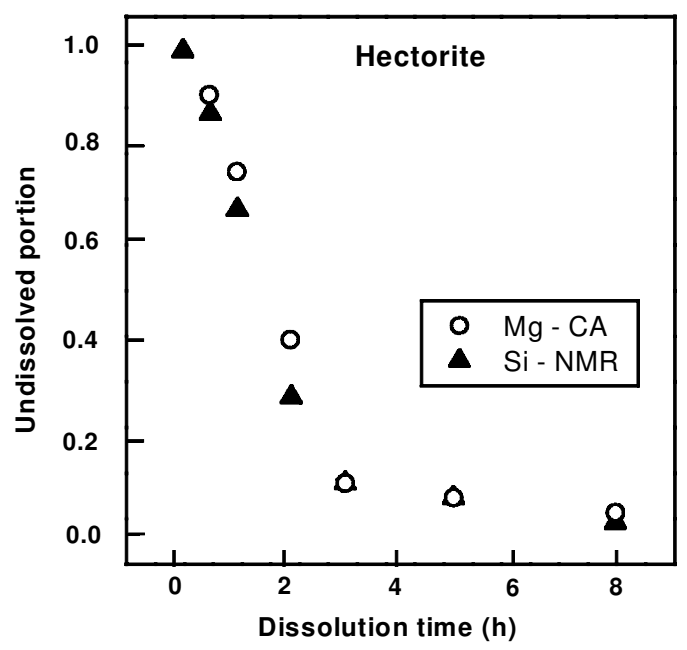

FIG. 3. Dissolution of hectorite in $1 \mathrm{M} \mathrm{HCl}$ at $20^{\circ} \mathrm{C} . \mathrm{Mg}$ data were obtained from solution analysis, $\mathrm{Si}$ data from the ${ }^{29} \mathrm{Si}$ MAS NMR spectra. Data from Gates et al. (1996). 
smectite layers at similar rates. Readily soluble, octahedral + tetrahedral and 'insoluble' portions of constituent atoms can be calculated from the dissolution curves, thus providing information on the distribution of atoms in the sample. Readily soluble portions include exchangeable cations and easily soluble admixtures such as goethite. Common 'insoluble' phases found in the fine fractions of bentonites are kaolinite, quartz, anatase and volcanic glass (Komadel et al., 1993; Číčel \& Komadel, 1994).

Catalytic activity of acid-treated smectites was tested using the reaction of 2,3-dihydropyran with methanol yielding the tetrahydropyranyl ether. Both Mg-rich and Al-rich montmorillonites, treated under the same conditions, were partially decomposed, but Mg-rich Cheto montmorillonite proved more susceptible to acid attack. The test reaction was a sensitive indicator of changes in clay acidity. Mild acid treatments exhibited high Brønsted acidities comparable with the CECs of the parent minerals and this was reflected in their high catalytic activity. Longer acid treatments caused a reduction of both acidity and catalytic activity due to the presence of fewer exchange sites resulting from the depopulation of the octahedral sheets (Breen et al., 1995a,b).

Four dioctahedral smectites of various chemical compositions, including a Mg-rich and an Al-rich montmorillonite, an Fe-beidellite and a ferruginous smectite, together with a hectorite were leached using treatment conditions selected to produce catalysts in which the octahedral sheet was depopulated in a controlled manner. The Brønsted acidity and catalytic activity of the resulting materials were highest for the samples prepared with the mildest acid treatments and decreased with increasing depletion of the octahedral sheets. The hectorite exhibited no catalytic activity, though cyclohexylamine desorption profiles suggested presence of Brønsted acid sites (Breen et al., 1997b). The recent study of cyclohexylamine desorption from $\mathrm{Ni}^{2+}$ - and $\mathrm{Al}^{3+}$-exchanged bentonite showed that this method need not distinguish Brønsted and Lewis acid sites unambiguously (Breen et al., 2000). The chemical composition of the starting material had no significant effect on the catalytic activity for the chosen test reaction. On the other hand, it plays a key role in determining the severity of the activation conditions required for the optimization of catalytic activity. FTIR and ${ }^{29} \mathrm{Si}$ MAS NMR spectroscopies provided evidence regarding the extent of the octahedral depletion, which correlated well with the acidity determined from thermal desorption of cyclohexylamine (Breen et al., 1997b). The number of acid sites obtained from cyclohexylamine desorption from a series of mildly acid-treated Cheto montmorillonite and hectorite samples agreed with the CEC data. No evidence of any free protons was found in the potentiometric titration curves, which proved that complete autotransfomation of the acid-treated samples had occurred over a short period. Acid sites associated with $\mathrm{Al}^{3+}$ or $\mathrm{Fe}^{3+}$ released from the Cheto montmorillonite layers during acid treatment and subsequent autotransformation catalysed the test reaction and produced the tetrahydropyranyl ether from 2,3-dihydropyran and methanol in $80 \%$ yield. The complete absence of catalytic activity in the acid-treated hectorite samples confirmed that acid sites associated with interlayer $\mathrm{Mg}^{2+}$ and $\mathrm{Li}^{+}$ were unable to catalyse this test reaction (Komadel et al., 1997).

The catalytic activity of acid-activated organoclays was tested for the conversion of $\alpha$-pinene to camphene (Breen et al., 1997a). The catalysts included a range of organosmectites containing tetramethylammonium, dodecyltrimethylammonium or octadecyltrimethylammonium cations at the 25 , 50 or $100 \%$ exchange level and subjected to selected acid-leaching procedures. The organic cation content and extent of acid dissolution was controlled by IR spectroscopy. The conditions used for acid leaching seldom removed extensive amounts of organocation and the yields (40\% conversion to camphene) compared favourably with those reported for pillared clays. Acidleached tetramethylammonium clays were the most active with yields four times higher than the corresponding parent clay. Acid-leached dodecyltrimethylammonium and octadecyltrimethylammonium clays were only active when the organocations occupied no more than $25 \%$ of the exchange sites (Breen et al., 1997a).

Acid catalysts were prepared by heating of $\mathrm{NH}_{4}$ saturated montmorillonite at $200-600^{\circ} \mathrm{C}$ for $24 \mathrm{~h}$ via decomposition of the cation, $\mathrm{NH}_{4}^{+} \rightarrow \mathrm{NH}_{3} \uparrow+$ $\mathrm{H}^{+}$, and their catalytic activity was tested in acetylation of 3,4,5-trimethoxybenzaldehyde with acetic anhydride. This reaction was sufficiently sensitive to the different catalyst modifications making it a suitable test for catalytic activity of modified montmorillonites. Most of the prepared catalysts were able to catalyse the test reaction and 
produce diacetate in yields $>50 \%$. The most active catalyst, obtained upon heating at $300^{\circ} \mathrm{C}$, was only slightly less effective than the commercially available acid-activated K10 catalyst (Jankovič \& Komadel, 2000).

\section{Reduction of structural Fe(III)}

Less common than acid activation are chemical treatments leading to a modification of the negative layer charge in smectites. The layer charge is perhaps the most important characteristic of smectites, connected with many properties of these minerals; therefore its increase via Fe(III) reduction and the decrease via Li-fixation upon heating has been intensively investigated in our laboratories. At least some Fe(III) occurs in various dioctahedral smectites including most montmorillonites, beidellites and illites, and $\mathrm{Fe}(\mathrm{III})$ is the dominant central atom in octahedral sheets of nontronites. Reduction of structural $\mathrm{Fe}$ (III) to $\mathrm{Fe}(\mathrm{II})$ in smectites profoundly affects many fundamental properties of the mineral, including layer charge, CEC, cation fixation, swelling pressure and water-holding capacity, specific surface area, hydraulic conductivity, colour, magnetic exchange interactions, etc. The ability to manipulate the oxidation state to modify clay properties in situ could be of great benefit to agriculture, industry and the environment. In many situations, however, such benefits depend on the stability of the reduced oxidation state (Stucki, 1988).

The most effective method currently used to reduce structural $\mathrm{Fe}(\mathrm{III})$ and prepare reduced smectites is reduction by sodium dithionite added to a smectite dispersion in the presence of a citrate and bicarbonate buffer while the vessel is being purged with $\mathrm{N}_{2}$. This treatment led to $>90 \%$ reduction in ferruginous smectite and nontronite (Komadel et al., 1990, 1995) but to only $\sim 60 \%$ reduction in griffithite, which is an Fe-rich trioctahedral smectite with dioctahedral domains, in which a negative charge is located on the tetrahedral sheets and a positive charge on the octahedral sheets. The lower reducibility of Fe(III) in griffithite relative to nontronites may be due to the differences in structure between griffithite and nontronites (Komadel et al., 2000). Reduced dioctahedral Fe-rich smectites are unstable materials in air, undergoing rapid and complete reoxidation with oxygen in water dispersions. The structural $\mathrm{OH}$ content of reduced-reoxidized nontronite is $\sim 15-20 \%$ less than in the original sample, indicating that the structure remains partially dehydroxylated even after reoxidation. Mössbauer spectra of reoxidized samples exhibited $\mathrm{Fe}$ (III) doublets of larger quadrupole splitting compared with those in the unaltered sample, suggesting that $\mathrm{Fe}$ (III) is in a more distorted environment after the reduction-reoxidation treatment (Komadel et al., 1995). Manceau et al., (2000) showed that migration of $\mathrm{Fe}$ from cis- to trans-sites occurred during the reduction process. Some of the Fe atoms occupy trans-sites in the reduced state, forming small trioctahedral domains within the structure of reduced nontronite.

\section{Li fixation}

Heating of Li-saturated montmorillonites at $250-300^{\circ} \mathrm{C}$ for several hours is known to cause their loss of expandability and CEC (Hofmann \& Klemen, 1950). Li fixation and resultant changes in swelling have served to distinguish between different smectites in that the irreversible collapse of the layers of Li-montmorillonite after heating was proposed to be the criterion to distinguish montmorillonite from beidellite (Greene-Kelly, 1953). Calvet \& Prost (1971) reported fixation of different amounts of $\mathrm{Li}^{+}$in Camp Berteaux montmorillonite upon heating for $24 \mathrm{~h}$ at $108-220^{\circ} \mathrm{C}$. Indeed, a series of reduced-charge montmorillonites (RCM) were prepared from different minerals by heating at various temperatures in the $105-300^{\circ} \mathrm{C}$ range (Madejová et al., 1996, 2000a; Hrobáriková et al., 2001). The amount of fixed $\mathrm{Li}(\mathrm{I})$ increased with the temperature, confirming the successful preparation of a set of samples of variable layer charge from the same parent Li-montmorillonite by varying only preparation temperature. Heating for different periods of time at 135 or $150^{\circ} \mathrm{C}$ showed that the extent of $\mathrm{Li}$ fixation increased with the duration of the treatment (Bujdák et al., 1991).

The effect of heating temperature on the CEC of Li-saturated smectites is presented in Fig. 4. The CEC values for all three montmorillonites decreased gradually with increasing temperature up to $200^{\circ} \mathrm{C}$, with final CEC values of 12 to $22 \%$ of that for the unheated sample. These data show that a substantial portion of $\mathrm{Li}^{+}$ions was fixed in the layers of all three montmorillonites investigated, upon heating at $200^{\circ} \mathrm{C}$ for $24 \mathrm{~h}$, similar to that 
observed for other montmorillonites (Komadel et al., 1996a; Hrobáriková et al., 2001). On the other hand, a much smaller decrease in the layer charge with heating temperature was observed for Stebno Fe-beidellite and SWa-1 ferruginous smectite, i.e. the minerals with prevailing tetrahedral charge. The CECs of ST200 and SWa200 (the number indicates the preparation temperature of $200^{\circ} \mathrm{C}$ ) were only reduced to 67 and $83 \%$, respectively, of their original values. Clearly, some $\mathrm{Li}$ fixation occurred in all smectites upon heating at $200^{\circ} \mathrm{C}$; however, the extent of fixation decreased with decreasing proportion of octahedral charge (Madejová et al., 2000a,b). This is in agreement with previous studies (e.g. Jaynes \& Bigham, 1987).

Series of RCM with gradually decreasing layer charge were prepared from montmorillonites of varying chemical composition. Heating the samples at temperatures up to $120^{\circ} \mathrm{C}$ caused some $\mathrm{Li}$ fixation but initiated only minor changes in the sorption properties. The biggest changes in the properties were observed among the samples prepared at $130-200^{\circ} \mathrm{C}$ (Fig. 5), while using higher temperatures had much less effect (Bujdák et al., 1992; Hrobáriková \& Komadel, 2002). The most extensive reduction in CEC in these experiments, by $81 \%$ after heating at $300^{\circ} \mathrm{C}$, was obtained

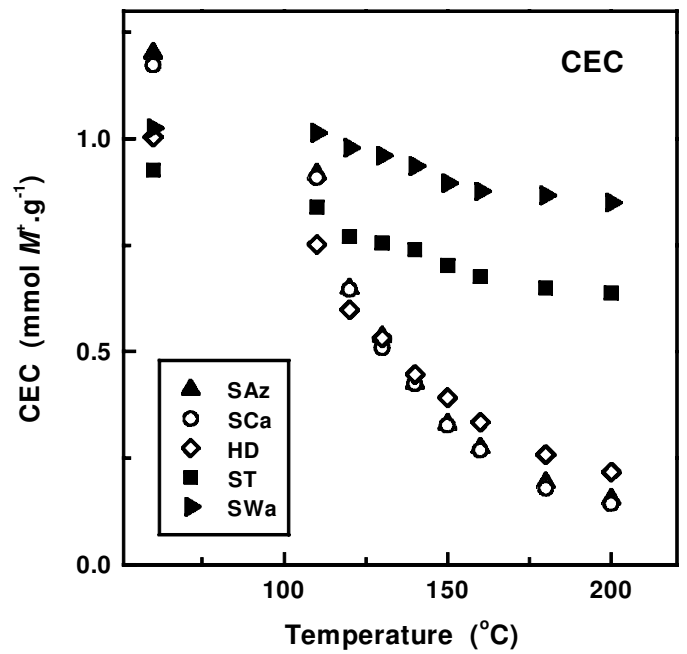

FIG. 4. Cation exchange capacities for SAz-1 (Cheto, Arizona), SCa-2 (Otay, California) and Horní Dunajovice (HD) (Czech Republic) montmorillonites, Stebno (ST) Fe-beidellite (Czech Republic) and SWa-1 ferruginous smectite (Grant County, Washington) heated at various temperatures for $24 \mathrm{~h}$. Figure from Madejová et al. (2000a). with Otay montmorillonite, the mineral of the highest octahedral and the smallest tetrahedral charge studied.

The parent Kriva Palanka montmorillonite and the samples KP110 and KP130 retained similar amounts of water under the same conditions, thus showing that the decreased negative charge on the layers had only a minor influence on the water uptake at all relative humidities (RHs) investigated. A significantly decreased amount of water was retained by KP160 while KP300 adsorbed only $8 \%$ water at $100 \% \mathrm{RH}$. The basal spacings, obtained by in situ XRD at different RHs, of the parent montmorillonite and the samples KP110 and KP130 increased with RH, while those of KP160 and KP300 were independent of $\mathrm{RH}$ and were stable within experimental error at $\sim 10.4$ and $\sim 9.6 \AA$ A, respectively (Komadel et al., 2002).

Fixation of $\mathrm{Li}^{+}$ions in the structure upon heating at a temperature $120^{\circ} \mathrm{C}$ or higher caused the appearance of a new $\mathrm{OH}$-stretching band near $3670 \mathrm{~cm}^{-1}$ in the spectra of all the montmorillonites investigated, confirming the formation of local trioctahedral domains containing $\operatorname{Li}(\mathrm{I})$ in the previously vacant octahedral positions. No similar band was observed in the spectra of heated ferruginous smectites with prevailing tetrahedral charge. A gradual upward frequency shift and decrease in intensity of the $\mathrm{AlAlOH}$-bending band showed that $\mathrm{Li}(\mathrm{I})$ present in the layers caused pronounced perturbation of this $\mathrm{OH}-$ bending mode;

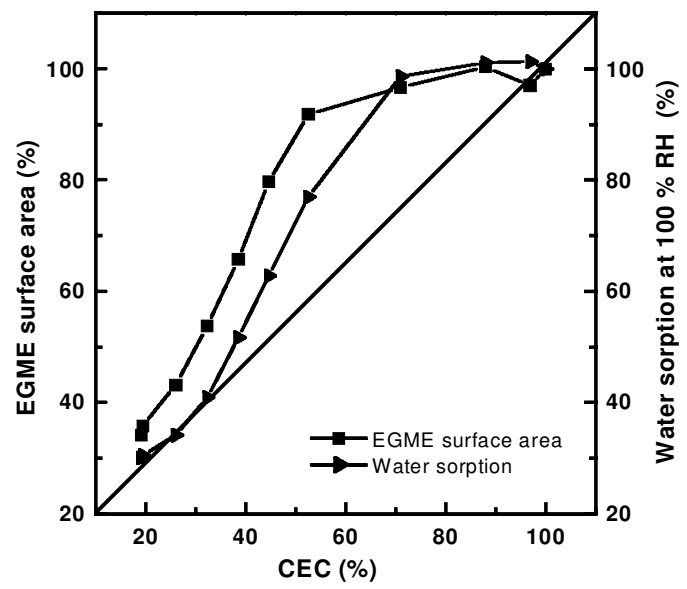

FIG. 5. Comparison of relative CECs and relative specific surface areas determined by ethylene glycol monoethyl ether adsorption for a series of reducedcharge Otay montmorillonite. Data from Hrobáriková \& Komadel (2002). 
whilst it only caused a small perturbation of the OH-bending mode near $850 \mathrm{~cm}^{-1}$ but it does activate a new $\mathrm{OH}$-bending mode near $803 \mathrm{~cm}^{-1}$. Reversible changes in the positions of the stretching $\mathrm{Si}-\mathrm{O}$ and bending $\mathrm{OH}$ bands in the spectra of $\mathrm{Fe}-$ beidellite and a ferruginous smectite proved that lithium was present in these minerals primarily in the hexagonal holes of the tetrahedral sheets (Madejová et al., 2000a).

Diffuse reflectance spectra in the near-infrared (NIR) region provided further evidence of substantial differences in the fixation of $\mathrm{Li}^{+}$in montmorillonites and in other dioctahedral smectites. Unheated samples showed a complex band near $7060 \mathrm{~cm}^{-1}$ assigned to the first overtone of the $\mathrm{OH}$ stretching mode of structural hydroxyl groups and bound $\mathrm{H}_{2} \mathrm{O}$. The $\mathrm{OH}$ combination bands appeared in the $4600-4300 \mathrm{~cm}^{-1}$ region. Spectra of heated montmorillonites showed an upward shift and splitting of the OH-overtone band into two components near 7170 and $7110 \mathrm{~cm}^{-1}$. The presence of a band near $7170 \mathrm{~cm}^{-1}$, assigned to the overtone of the $\mathrm{AlMgLiOH}$-stretching vibration, implied that local trioctahedral domains were created upon $\mathrm{Li}$ fixation in the previously vacant octahedral positions of montmorillonites. The $\mathrm{OH}-$ combination bands were shifted to higher frequencies and a new band appeared near $4472 \mathrm{~cm}^{-1}$ in the spectra of montmorillonites heated above $130^{\circ} \mathrm{C}$. No feature indicating $\mathrm{Li}(\mathrm{I})$ in the structure of $\mathrm{Fe}$ beidellite or ferruginous smectite was observed in the NIR spectra (Madejová et al., 2000b).

The gradual decrease of the layer charge due to Li fixation led to a shift of the Si-O-stretching band to higher frequencies and to the appearance of new, weak, pyrophyllite-like bands near 1120 and $420 \mathrm{~cm}^{-1}$ (Madejová et al., 1996; Hrobáriková et al., 2001). A series of RCM was treated with $6 \mathrm{M}$ $\mathrm{HCl}$ at $95^{\circ} \mathrm{C}$ for periods up to $30 \mathrm{~h}$. Reaction solutions obtained were analysed for $\mathrm{Al}$ (Fig. 6), $\mathrm{Fe}, \mathrm{Mg}$ and $\mathrm{Li}$ and the solid reaction products were investigated using FTIR spectroscopy. Both analyses provided evidence that the extent of dissolution decreased with increased amounts of $\mathrm{Li}$ (I) fixed within the montmorillonite structure, i.e. with increased preparation temperature. Differences in the acid dissolution process reflected the fact that structural changes occurred within the samples presumably due to differing positions of the fixed Li. The EGME surface areas and XRD and HRTEM analyses of the series revealed an increased number of non-swelling interlayers in the samples prepared at 160 and $210^{\circ} \mathrm{C}$, which caused a substantially slower decomposition of these samples in $\mathrm{HCl}$. The calculated XRD patterns of samples prepared at 135 and $160^{\circ} \mathrm{C}$ confirmed the presence of $20 \%$ and $45 \%$ pyrophyllite-like layers, respectively, in these samples. Mixed-layer pyrophyllite-like/smectite and pyrophyllite-like crystals, containing only non-swelling interlayers, were found in the sample prepared at $210^{\circ} \mathrm{C}$. The results confirmed that the number of swelling interlayers in RCM substantially affects their dissolution rate in $\mathrm{HCl}$ (Komadel et al., 1996a). This is direct experimental evidence that protons do not attack the smectite particles from their edges only.

${ }^{29} \mathrm{Si}$ MAS NMR spectra revealed a consistent chemical shift to more negative values and increased line-width of the main $\mathrm{Si}$ resonance with increasing levels of fixed $\mathrm{Li}(\mathrm{I})$ (Gates et al., 2000). The ${ }^{29} \mathrm{Si}$ chemical shift of $-95.4 \mathrm{ppm}$ obtained for the sample prepared at $210^{\circ} \mathrm{C}$ agrees well with the value reported for pyrophyllite (Sanchez-Soto et al., 1993). This is consistent with the formation of pyrophyllite-like layers in RCM, as was observed in the IR spectra (Madejová et al., 1996), in increased numbers of non-swelling, pyrophyllite-like layers and in decreased specific surface area (Komadel et al., 1996a) for the same series of samples.

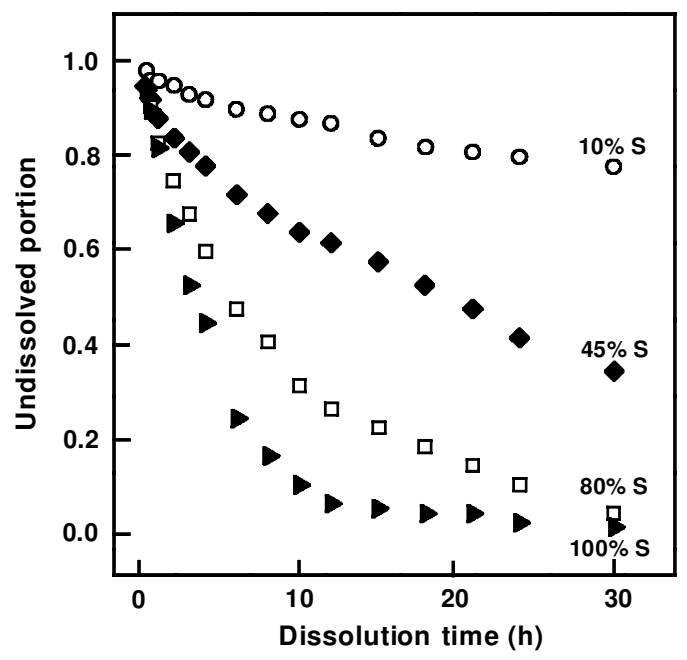

FIG. 6. Effect of non-swelling interlayers on dissolution of $\mathrm{Al}$ from reduced-charge montmorillonite in $6 \mathrm{M} \mathrm{HCl}$ at $95^{\circ} \mathrm{C}$. The percentage data indicate the content of swelling layers in the samples. Data from Komadel $e t$ al. (1996a). 
Absorption and specular reflectance FTIR and electron spin resonance spectroscopies were employed for analysis of sites of $\mathrm{Li}(\mathrm{I}), \mathrm{Cu}(\mathrm{II})$ and $\mathrm{Cd}(\mathrm{II})$ fixed in the structure of montmorillonite from Jelšový Potok (Slovakia) upon heating. The CEC values showed that the layer charge of the mineral decreased with increasing temperature of heating and that the amount of fixed cations was in the order $\mathrm{Li}(\mathrm{I})>\mathrm{Cu}(\mathrm{II})>\mathrm{Cd}(\mathrm{II})$. Analysis of the $\mathrm{OH}$-stretching region in the FTIR absorption spectra revealed that most of $\mathrm{Li}^{+}$ions migrated into the octahedral vacancies upon heating, thus creating local trioctahedral AlMgLiOH groupings. $\mathrm{Cu}(\mathrm{II})$ were trapped in the hexagonal cavities of the tetrahedral sheet, whereas $\mathrm{Cd}^{2+}$ ions are too large to enter deep enough into the hexagonal cavities to become fixed. While both $\mathrm{Cu}^{2+}$ and $\mathrm{Cd}^{2+}$ ions have the same charge, the ionic radius of $\mathrm{Cd}^{2+}$ is too large to penetrate close to the $\mathrm{OH}$ groups. Even though $\mathrm{Cu}^{2+}$ and $\mathrm{Li}^{+}$ions are of similar size and therefore expected to enter vacant octahedral sites, IR spectroscopy indicated that only $\mathrm{Li}^{+}$ions would migrate into the previously vacant octahedra. It appears that both the size and the charge of interlayer cations affect their final position after fixation upon heating (Madejová et al., 1999). After preparation at $300^{\circ} \mathrm{C}, \mathrm{Li}(\mathrm{I})$ were predominantly trapped in the previously vacant octahedra. $\mathrm{Cu}$ (II) were fixed deep in the hexagonal holes, where they substantially affected the vibration modes of Si-O bonds in the specular reflectance IR spectra. $\mathrm{Cu}$ (II) were partially coordinated by oxygen atoms from the mineral layers and by nitrogen atoms from pyridine molecules if present in the interlayers. The bigger $\mathrm{Cd}^{2+}$ ions were prevented from going as deep into the hexagonal holes as $\mathrm{Cu}(\mathrm{II})$ and their effect on $\mathrm{Si}-\mathrm{O}$ bonds was less pronounced (Karakassides et al., 1999).

The $\mathrm{Fe}(\mathrm{II})$ in chemically reduced smectite is normally readily reoxidized in air, but it can be partially stabilized by $\mathrm{Li}$ fixation upon heating. More than $80 \%$ of total $\mathrm{Fe}$ in ferruginous smectite SWa-1 was reduced to $\mathrm{Fe}(\mathrm{II})$, then $\mathrm{Li}^{+}$saturated, washed free of excess ions, freeze-dried, and heated in a $\mathrm{N}_{2}$ atmosphere at $260^{\circ} \mathrm{C}$ for $24 \mathrm{~h}$ to evoke $\mathrm{Li}$ fixation. This treatment caused partial stabilization of $\mathrm{Fe}$ (II) in the clay mineral structure. Chemical analysis, Mössbauer spectroscopy and IR spectroscopy proved that $>20 \%$ of total Fe was $\mathrm{Fe}$ (II) after reoxidation with oxygen in a water dispersion, a treatment which normally causes complete reoxidation of $\mathrm{Fe}(\mathrm{II})$ in reduced Na-smectites. Spectral fitting of the $\mathrm{OH}$-stretching band evident in the IR spectra indicated migration of $\mathrm{Li}^{+}$into the vacant octahedra. Some of the $\mathrm{OH}$ groups in the reoxidized smectite were found in local trioctahedral configurations, associated with the $\mathrm{AlFe}(\mathrm{II}) \mathrm{Li}$ or $\mathrm{Fe}(\mathrm{III}) \mathrm{Fe}(\mathrm{II}) \mathrm{Li}$ groupings of central atoms in the octahedral sheet (Komadel et al., 1999).

\section{Interactions with methylene blue}

Methylene blue (MB) is a cationic dye readily soluble in water. In aqueous solutions of low concentrations, MB cations partially associate as cationic dimers. The surfaces of clay minerals exhibit a strong affinity for MB cations. A partial protonation of $\mathrm{MB}$ cations may also take place at clay surfaces. MB-clay interaction is extremely sensitive for probing the surface properties of smectites in water suspensions. The cations are adsorbed via ion exchange, frequently accompanied by agglomeration. The agglomeration of $\mathrm{MB}$, at low loadings of $\mathrm{MB}$, is very sensitive to the layer charge of smectites. Hence, visible absorption spectroscopy (VIS) of MB-smectite dispersions is a simple, but extremely sensitive method to probe layer charge density of natural and/or chemically modified smectites. This was the reason for investigating the effect of layer charge on MBmontmorillonite interactions in suspension using different montmorillonites. The nearly perpendicular orientation of MB cations at the clay mineral basal surface, recently proved for micas (Hähner et al., 1996), facilitates the formation of large, multication dye agglomerates that keep the basal spacing of MB-clay complexes at $\sim 1.75 \mathrm{~nm}$. If the orientation of $\mathrm{MB}$ cations was parallel to the surface such an agglomeration would not occur. Since each form of MB (monomer, dimer, higher agglomerate) absorbs visible light at a different wavelength, surfaces of different layer-charge densities exhibit different absorption spectra for the resulting clay mineral-dye dispersion. The VIS spectra of $\mathrm{MB}$ with $\mathrm{Na}$ - and $\mathrm{H}$-smectite dispersions provided information about the formation of protonated dye cations, dimers, and higher agglomerates on the clay surface. The different amounts of the various dye forms were compared with negative layer charge distributions of the clay minerals used, obtained by the alkylammonium method. The formation of $\mathrm{MB}$ dimers and higher agglomerates reflected sensitively the layer-charge density of the smectites. Methylene blue cations formed predomi- 
nantly larger agglomerates at the surface of the smectites with high charge density, whereas much less dye agglomeration was observed for the samples of lower layer-charge density, presumably because of the greater distances between the adsorbed MB cations (Bujdák et al., 1998).

The layer-charge decrease, induced by $\mathrm{Li}$ fixation, was correlated with the trends in the VIS spectra of MB-RCM dispersions. Apparently, the distribution of the negative surface charge on the clay minerals controls the distance between the adsorbed MB cations and thus affects the formation of MB dimers and larger agglomerates. Both the CEC values and the spectra of MB-smectite dispersions clearly correlated with the extensive reduction of the layer-charge density of the RCM upon $\mathrm{Li}$ fixation and were in accord with the effect of treatment temperature and locus of charge described above. The CEC data and MB spectra were sensitive to the lesser charge reduction in the $\mathrm{Fe}$-rich beidellite and ferruginous smectite, which is related to the low octahedral charge of these minerals. Following heating at higher temperatures $\left(120-160^{\circ} \mathrm{C}\right)$, slightly higher $\mathrm{Li}$ fixation was indicated by CEC values; however, no charge reduction was confirmed by $\mathrm{MB}$ spectra. The spectra of protonated $\mathrm{MB}$ is very distinctive and the release of protons accompanying $\mathrm{Li}$ fixation in Fe-rich smectites heated at 180 or $200^{\circ} \mathrm{C}$ was detected in the spectra of MB-clay dispersions and confirmed by potentiometric titrations (Bujdák \& Komadel, 1997; Bujdák et al., 2001).

\section{ACKNOWLEDGMENTS}

The author acknowledges with appreciation the contributions of all coauthors of the cited papers for the results obtained and resulting interpretations and Prof. C. Breen for improving an earlier version of this paper. The Slovak Grant Agency VEGA is acknowledged for partial financial support of the work covered in this study.

\section{REFERENCES}

Adams J.M. (1987) Synthetic organic chemistry using pillared, cation-exchanged and acid-treated montmorillonite catalysts - A review. Applied Clay Science, 2, 309-342.

Barshad I. (1969) Preparation of H saturated montmorillonites. Soil Science, 108, 38-42.

Breen C., Forsyth J., Yarwood J. and Hughes T. (2000) Thermal desorption-degradation of cyclohexylamine over $\mathrm{Ni}^{2+}$ - and $\mathrm{Al}^{3+}$-exchanged bentonite studied using evolved gas analysis (TG-EGA) and diffuse reflectance spectroscopy (DRIFTS). Physical Chemistry Chemical Physics, 2, 3887-3892.

Breen C., Madejová J. \& Komadel P. (1995a) Characterisation of moderately acid-treated, sizefractionated montmorillonites using IR and MAS NMR spectroscopy and thermal analysis. Journal of Materials Chemistry, 5, 469-474.

Breen C., Madejová J. \& Komadel P. (1995b) Correlation of catalytic activity with infrared-red, ${ }^{29}$ Si MAS NMR and acidity data for HCl-treated fine fractions of montmorillonites. Applied Clay Science, 10, 219-230.

Breen C., Watson R., Madejová J., Komadel P. \& Klapyta Z. (1997a) Acid-activated organoclays: Preparation, characterisation and catalytic activity of acid-treated tetra-alkylammonium exchanged smectites. Langmuir, 13, 6473-6479.

Breen C., Zahoor F.D., Madejová J. \& Komadel P. (1997b) Characterisation and catalytic activity of acid treated, size fractionated smectites. Journal of Physical Chemistry B, 101, 5324-5331.

Brown D.R. (1994) Review: Clays as catalyst and reagent supports. Geologica Carpathica, Series Clays, 45, 45-56.

Bujdák J. \& Komadel P. (1997) Interaction of methylene blue with reduced charge montmorillonite. Journal of Physical Chemistry B, 101, 9065 -9068.

Bujdák J., Janek M., Madejová J. \& Komadel P. (1998) Influence of the layer charge density of smectites on the interaction with methylene blue. Journal of Chemical Society, Faraday Transactions, 94, $3487-3492$.

Bujdák J., Janek M., Madejová J. \& Komadel P. (2001) Methylene blue interactions with reduced charge smectites. Clays and Clay Minerals, 49, 244-254.

Bujdák J., Petrovičová I. \& Slosiariková H. (1992) Study of water - reduced charge montmorillonite system. Geologica Carpathica, Series Clays, 43, $109-111$.

Bujdák J., Slosiariková H., Nováková L. \& Čćčel B. (1991) Fixation of lithium cations in montmorillonite. Chemical Papers, 45, 499-507.

Calvet R. \& Prost R. (1971) Cation migration into empty octahedral sites and surface properties of clays. Clays and Clay Minerals, 19, 175-186.

Číčel B. \& Komadel P. (1994) Structural formulae of layer silicates. Pp. $114-136$ in: Quantitative Methods in Soil Mineralogy (J.E. Amonette \& L.W. Zelazny, editors). Soil Science Society of America Miscellaneous Publications, Soil Science Society of America, Madison, Wisconsin.

Fahn R. \& Fenderl K. (1983) Reaction products of organic dye molecules with acid-treated montmorillonite. Clay Minerals, 18, 447-458.

Farmer V.C. (1974) Layer silicates. Pp. 331-363 in: Infrared Spectra of Minerals (V.C. Farmer, editor). 
Monograph 4, Mineralogical Society, London.

Gates W.P., Komadel P., Madejová J., Bujdák J., Stucki J.W. \& Kirkpatrick R.J. (2000) Electronic and structural properties of reduced-charge montmorillonites. Applied Clay Science, 16, 257 -271.

Gates W.P., Madejová J., Janek M. \& Komadel P. (1996) Spectroscopic study of hectorite dissolution in $\mathrm{HCl}$. Acta Universitas Carolinae Geologica 38, $183-191$.

Greene-Kelly R. (1953) The identification of montmorillonoids in clays. Journal of Soil Science, 4, $233-237$.

Hähner G., Marti A., Spencer N.D. \& Caseri W.R. (1996) Orientation and electronic structure of methylene blue on mica: A near edge X-ray absorption structure spectroscopic study. Journal of Chemical Physics, 104, 7749-7757.

Hofmann U. \& Klemen R. (1950) Verlust der Austauschfähigkeit von Lithiuminonen an Bentonit durch Erhitzung, Zeitschrift für anorganische und allgemeine Chemie, 262, 95 -99.

Hrobáriková J. \& Komadel P. (2002) Sorption properties of reduced charge montmorillonite. Geologica Carpathica, 53, $93-98$.

Hrobáriková J., Madejová J. \& Komadel P. (2001) Effect of heating temperature on Li fixation, layer charge and properties of fine fractions of bentonites. Journal of Materials Chemistry, 11, $1452-1457$.

Jagiełło J. (1994) Stable numerical solution of the adsorption integral equation using splines. Langmuir, 10, $2778-2785$.

Janek M. \& Komadel P. (1993) Autotransformation of $\mathrm{H}$-smectites in aqueous solution. Effect of octahedral iron content. Geologica Carpathica Series Clays, 44, $59-64$.

Janek M. \& Komadel P. (1999) Acidity of proton saturated and autotransformed smectites characterised with proton affinity distribution. Geologica Carpathica, 50, 373-378.

Janek M., Komadel P. \& Lagaly G. (1997) Effect of autotransformation on the layer charge of smectites determined by the alkylammonium method. Clay Minerals, 32, 623-632.

Janek M. \& Lagaly G. (2001) Proton saturation and rheological properties of smectite dispersions. Applied Clay Science, 19, $121-130$.

Jankovič L'. \& Komadel P. (2000) Catalytic properties of a heated ammonium-saturated dioctahedral smectite. Collection of Czechoslovak Chemical Communications, 65, 1527-1536.

Jaynes W.F. \& Bigham J.M. (1987) Charge reduction, octahedral charge, and lithium retention in heated, Li-saturated smectites. Clays and Clay Minerals, 35, $440-448$.

Karakassides M.A., Madejová J., Arvaiová B., Bourlinos A., Petridis D. \& Komadel P. (1999) Location of $\mathrm{Li}(\mathrm{I}), \mathrm{Cu}(\mathrm{II})$, and $\mathrm{Cd}(\mathrm{II})$ in heated montmorillonite: Evidence from specular reflectance infrared and electron spin resonance spectroscopies. Journal of Materials Chemistry, 9, 1553-1558.

Komadel P. \& Číčel B. (1987) Sedimentation volumes of H-montmorillonites. I. The effect of the conditions of preparation. Ceramics-Silikáty, 31, $247-253$.

Komadel P. \& Číčel B. (1988) Sedimentation volumes of H-montmorillonites. II. Influence of anions and temperature. Proceedings of 10th Conference on Clay Mineralogy and Petrology, Ostrava 1986, (J. Konta, editor), 267-272.

Komadel P. \& Číčel B. (1991) Sedimentation volumes of H-montmorillonites. III. Natrification. CeramicsSilikáty, 35, $121-126$.

Komadel P. \& Schomburg J. (1993) Swelling of acid treated bentonites. Ceramics-Silikáty, 37, 97-99.

Komadel P., Lear P.R. \& Stucki J.W. (1990) Reduction and reoxidation of nontronite: Extent of reduction and reaction rates, Clays and Clay Minerals, 38, $203-208$.

Komadel P., Stucki J.W. \& Č́ćcel B. (1993) Readily $\mathrm{HCl}$-soluble iron in the fine fractions of some Czech bentonites. Geologica Carpathica, Series Clays, 44, $11-16$.

Komadel P., Madejová J. \& Stucki J. W. (1995) Reduction and reoxidation of nontronite: Questions of reversibility. Clays and Clay Minerals, 43, $105-110$.

Komadel P., Bujdák J., Madejová J., Šucha V. \& Elsass F. (1996a) Effect of non-swelling layers on the dissolution of reduced-charge montmorillonite in hydrochloric acid. Clay Minerals, 31, 333-345.

Komadel P., Madejová J., Janek M., Gates W.P., Kirkpatrick R.J. \& Stucki J.W. (1996b) Dissolution of hectorite in inorganic acids. Clays and Clay Minerals, 44, 228-236.

Komadel P., Janek M., Madejová J., Weekes A. \& Breen C. (1997) Acidity and catalytic activity of mildly acid-treated Mg-rich montmorillonite and hectorite. Journal of Chemical Society, Faraday Transactions, 93, $4207-4210$.

Komadel P., Madejová J. \& Stucki J. W. (1999) Partial stabilization of $\mathrm{Fe}$ (II) in reduced ferruginous smectite by Li fixation. Clays and Clay Minerals, 47, $458-465$.

Komadel P., Madejová J., Laird D.A., Xia Y. \& Stucki J. W. (2000) Reduction of $\mathrm{Fe}(\mathrm{III})$ in griffithite. Clay Minerals, 35, 625-634.

Komadel P., Hrobáriková J., Smrčok L'. \& Koppelhuber-Bitschnau B. (2002) Hydration of reduced-charge montmorillonite. Clay Minerals, 37, $543-550$.

Lintnerová O., Šucha V. \& Streško V. (1999) Mineralogy and geochemistry of acid mine Feprecipitates from the main Slovak mining regions. Geologica Carpathica, 50, 395 -404.

Low P.F. (1980) The swelling of clay. II. Montmorillonites. Soil Science Society of America 
Journal, 44, 667-676.

Luca V. \& MacLachlan D.J. (1992) Site occupancy in nontronite studied by acid dissolution and Mössbauer spectroscopy. Clays and Clay Minerals, 40, 1-7.

Madejová J., Arvaiová B. \& Komadel P. (1999) FTIR spectroscopic characterisation of thermally treated $\mathrm{Cu}^{2+}, \mathrm{Cd}^{2+}$, and $\mathrm{Li}^{+}$montmorillonites. Spectrochimica Acta A, 55, $2467-2476$.

Madejová J., Bujdák J., Gates W.P. \& Komadel P. (1996) Preparation and infrared spectroscopic characterization of reduced-charge montmorillonite with various Li contents. Clay Minerals, 31, 233-241.

Madejová J., Bujdák J., Janek M. \& Komadel P. (1998) Comparative FT-IR study of structural modifications during acid treatment of dioctahedral smectites and hectorite. Spectrochimica Acta A, 54, 1397-1406.

Madejová J., Bujdák J., Petit S. \& Komadel P. (2000a) Effects of chemical composition and temperature of heating on the infrared spectra of Li-saturated dioctahedral smectites. (I) Mid-infrared region. Clay Minerals, 35, 739-751.

Madejová J., Bujdák J., Petit S. \& Komadel P. (2000b) Effects of chemical composition and temperature of heating on the infrared spectra of Li-saturated dioctahedral smectites. (II) Near-infrared region. Clay Minerals, 35, 753-751.

Manceau A., Drits V.A., Lanson B., Chateigner G., Wu J., Huo D., Gates W.P. \& Stucki J.W. (2000) Oxidation-reduction mechanisms of iron in dioctahedral smectites. 1. Structural chemistry of oxidized reference nontronites. American Mineralogist, 85, $133-152$.
Moenke H.H.W. (1974) Silica, the three-dimensional silicates, borosilicates, and berylium silicates. Pp.365-382 in: Infrared Spectra of Minerals (V.C. Farmer, editor). Monograph 4, Mineralogical Society, London.

Norrish, K. (1954) The swelling of montmorillonites. Discussions of Faraday Society, 18, 120-134.

Novák I. \& Číčel B. (1978) Dissolution of smectites in hydrochloric acid: II. Dissolution rate as a function of crystallochemical composition. Clays and Clay Minerals, 26, $341-344$.

Osthaus B.B. (1956) Chemical determination of tetrahedral ions in nontronite and montmorillonite. Clays and Clay Minerals, 2, 404-417.

Rhodes C. N. \& Brown D. R. (1994) Catalytic activity of acid-treated montmorillonite in polar and nonpolar reaction media. Catalysis Letters, 24, $285-291$.

Sanchez-Soto P., Sobrados I., Sanz J. \& PerezRodriguez J.L. (1993) 29-Si and 27-Al MAS NMR study of the thermal transformations of pyrophyllite. Journal of the American Ceramic Society, 76, $3024-3028$.

Siddiqui M.H.K. (1968) Bleaching Earths. Pergamon Press, London.

Stucki J.W. (1988) Structural iron in smectites. Pp. 625-675 in: Iron in Soils and Clay Minerals, (J.W. Stucki, B.A. Goodman \& U. Schwertmann, editors). D. Reidel, Dordrecht, The Netherlands.

Tkáč I., Komadel P. \& Müller D. (1994) Acid-treated montmorillonites - a study by ${ }^{29} \mathrm{Si}$ and ${ }^{27} \mathrm{Al}$ MAS NMR. Clay Minerals, 29, 11-19. 